УДК $371.72(438)$

\title{
ПОГЛЯДИ АНДЖЕЯ СНЯДЕЦЬКОГО НА РОЗВИТОК ФІЗИЧНОГО ВИХОВАННЯ ДІТЕЙ ТА МОЛОДІ В ПОЛЬЩІ
}

\author{
Володимир Пасічник ${ }^{1}$ \\ 1Університет Яна Кохановського в Кельцях, Філія в Пйотркуві Трибунальському, Польща, wlod_pas@ o2.pl
}

https://doi.org/10.29038/2220-7481-2019-02-16-20

\begin{abstract}
Анотації
Bcmyn. У статті розкрито просвітницьку діяльність у галузі фізичного виховання видатного польського вченого А. Снядецького. Становлення й розвиток системи фізичного виховання дітей та молоді на польських землях наприкінці XVIII ст. проходило в дуже складних суспільно-політичних й економічних умовах, що пов'язано, передусім, з угратою національної незалежності. Землі Польщі після завершення наполеонівських війн поділено між трьома державами - Росією, Пруссією та Австро-Угорщиною, - що спричинило значний спад функціонування економіки, національної культури й освіти. Характерним для польської освіти тих часів, зокрема й для фізичного виховання молодого покоління, стала відмінність функціонування організаційно-навчальних форм у різних типах навчальних закладів, які перебували під контролем іноземних адміністрацій. Саме в цей складний час польської історії довелося жити й працювати видатному польському вченому Анджею Снядецькому. Методи досліджения вивчення літературних джерел, документальних матеріалів, теоретичний аналіз і синтез отриманих даних. Результати дослідження. Анджей Снядецький (1768-1838), польський хімік, біолог, лікар, але також філософ та педагог, був яскравим прикладом представника епохи Просвітництва, ученого, якого вважають у Польщі батьком хімічних наук, гігієни, дієтології та фізичного виховання. Одним із найважливіших творів А. Снядецького, у якому він висловив свою громадянську позицію, турботу про майбутне польського народу, передусім про його біологічний потенціал, $є$ праця «Про фізичне виховання дітей», публікація якої розпочалася в 1805 р. А. Снядецький був критично налаштований до домашньої системи освіти й виховання як серед шляхти, так і стосовно міщанських сімей. У своїй критиці він особливу увагу звертав на відсутність у домашній освіті та вихованні чітких засад і правних норм, на однобокість процесу виховання, спрямованого в основному на розвиток духовної сфери 3 нехтуванням фізичного розвитку дітей і молоді. У своїй праці А. Снядецький представив власну концепцію й програму виховання. Висновки. Ключову роль, на думку вченого, у всебічному вихованні дітей та молоді повинно відігрівати фізичне виховання, суттєвим елементом якого є рухова активність на свіжому повітрі та гартування й гігієна тіла. Погляди вченого на виховання дітей та молоді ефективно інтегрували природниче, медичне й педагогічне знання. Значну роль у формуванні та розвитку концепції виховання А. Снядецького відіграли ідеї французьких просвітителів, особливо Ж.-Ж. Руссо.
\end{abstract}

Ключові слова: фізичне виховання, гігієна, рухова активність, здоров'я, діти.

Владимир Пасечник. Взгляды Анджея Снядецкого на развитие физического воспитания детей и молодежи в Польше. Введение. В статье раскрывается просветительская деятельность видающегося польского ученного Анджея Снядецкого. Становление и развитие системы физического воспитания детей и молодежи в Польше на польских землях под конец XVIII в. проходило в исключительно трудных политических и экономических условиях, что было следствием потери национальной независимости. Польские земли после завершения наполеоновских войн разделены между тремя государствами - Австро-Венгрией, Россией и Пруссией, - вследствие чего наступил кризис в экономическом, культурном и образовательном развитии. Характерной чертой польского образования того времени, в том числе и физического воспитания молодого поколения, стала отменность в функционировании организационно-образовательных форм в разного типа учебных заведений, которые находились под внимательным контролем иностранных администраций. Именно в этот сложный период польской истории пришлось жить и работать видающемуся польскому ученному Анджею Снядецкому. Методы исследования. Изучение литературных источников, документальных материалов, теоретический анализ и синтез полученных результатов. Результаты исследования. Анджей Снядецкий (1768-1838), химик, биолог, врач, но и философ и педагог, был ярким представителем периода Просвещения, которого считают в Польше отцом химических наук, гигиены, диетологии и физического воспитания. Одним из наиболее важных произведений А. Снядецкого, в котором он выразил свою гражданскую позицию, заботу о будущем польского народа, в первую очередь - о его биологическом потенциале, является его робота «О физическом воспитании детей», публикация которой началась с 1805 г. А. Снядецкий критически относился к домашней системе воспитания и образования как среди шляхты, так и среди мещанских семей. В своей критике он особое внимание уделял отсутствию в домашним воспитании чётких принципов и правовых норм, односторонности процесса воспитания, направленного в основном на духовное развитие с пренебрежительным отношением к физическому развитию детей и молодёжи. В своей работе А. Снядецкий представил свою концепцию и программу воспитания. Bыводы. Ключевую роль, по мнению ученого, во

16 ISSN 2410-2156 (Online), ISSN 2220-7481 (Print)

(c) 2019 Східноєвропейський національний університет імені Лесі Українки. Ця стаття відкритого доступу на умовах CC BY-NC 4.0 
всестороннем развитии детей и молодежи должно играть физическое воспитание детей и молодёжи, ключевыми элементами, которого является двигательная активность на свежим воздухе, а также закаливание и гигиена тела. Взгляды ученого на воспитание детей и молодежи эффективно интегрировали природные, медицинские и педагогические знания. Значительную роль на формирование и развитие взглядов А. Снядецкого имели идеи французских просветителей, особенно Ж.-Ж. Руссо.

Ключевые слова: физическое воспитание, гигиена, двигательная активность, здоровье, дети.

Vladimir Pasechnyk. The Views of Andrzej Snyadetsky on the Development of the Theory and Practice of Physical Education in Poland. Introduction. The article is devoted to the educational activities of outstanding polish scientist Andrzej Snyadetsky. The formation and development of the system of physical education of children and young people on Polish lands at the end of the XVIII century took place in extremely difficult political and economic conditions, which was the result of the loss of national independence. Polish lands after the end of the Napoleonic wars were divided between the three countries Austria-Hungary, Russia and Prussia, which resulted with crisis in economic, cultural and educational development. A characteristic feature of the Polish education of that time, including the physical education of the young generation, was the cancellation of the functioning of organizational and educational forms in various types of educational institutions, which were under the careful supervision of foreign administrations. It was during this difficult period of Polish history that the emerging Polish scientist Andrzej Snyadetsky had to live and work. Research Methods. The study of literary sources, documentary materials, theoretical analysis and synthesis of the results. The Results of the Study. Andrzej Sniadecki (1768-1838), a chemist, biologist, doctor, but also a philosopher and teacher was a prominent representative of the enlightenment period, who is considered the father in Poland of chemical sciences, hygiene, dietology and physical education. One of the most important works of Snyadetsky, is the one in which he expressed his civil position and concern for the future of the Polish people. First of all about its biological potential is its work «On the physical education of children», the publication of which began in 1805. A. Snyadetsky was critical of the domestic system of upbringing and education, both among the gentry and among the petty-bourgeois families. In his criticism A. Shyadetsky devoted particular attention to the absence of clear principles and legal norms in home education, the one-sided process of education aimed mainly at spiritual development, disregarding the physical development of children and young people. In his work A.Snyadesky presented his concept and education program. Conclusions. According to the scientist, the key role in the physical activity in fresh air, as well as stabbing and body hygiene. The view of the scientist on the upbringing of children and young people effectively integrated natural, medical and pedagogical knowledge. Significant role on the formation and development of the views of A. Snyadetsky had the ideas of the French enlighteners, especially J.-J. Rousseau.

Key words: physical education, hygiene, physical activity, health, children's.

Вступ. Становлення й розвиток системи фізичного виховання дітей та молоді на польських землях наприкінці XVIII ст. проходило в дуже складних суспільно-політичних та економічних умовах, що пов'язано, передусім, з утратою національної незалежності. Землі Польщі після завершення наполеонівських війн поділено між трьома державами - Росією, Пруссією та Австро-Угорщиною, - що спричинило значний спад функціонування економіки, національної культури та освіти. Характерним для польської освіти тих часів, зокрема й для фізичного виховання молодого покоління, стала відмінність функціонування організаційно-навчальних форм у різних типах навчальних закладів, які перебували під пильним контролем іноземних адміністрацій. Саме в цей складний час польської історії довелося жити й працювати видатному польському вченому Анджею Снядецькому.

Поряд із педагогічними концепціями, які обгрунтовували значення фізичного виховання для всебічного розвитку молодого покоління в Європі у XVIII та XIX ст., потрібно вказати на надзвичайно важливе значення реформаторської діяльності Комісії народної освіти (1773-1794 рр.) у розвитку національної системи фізичного виховання дітей та молоді в Польщі. Численні приклади вказують на активне впровадження фізичного виховання в польські школи навіть після закінчення функціонування комісії. Потрібно також зазначити, що в період іiі діяльності школи не мали гімнастичних залів, відповідного фізкультурного інвентарю, не було методичних посібників, а головне - фахівців із цієї галузі педагогіки. Однак КНО, ураховуючи наявні умови, вимагала проводити заняття з фізичного виховання в різних типах шкіл на свіжому повітрі із широким застосуванням рухливих ігор, основних рухів (ходьба, біг, метання предметів, стрибки, лазіння тощо) [7].

Мета дослідження - проаналізувати наукову та просвітницьку діяльність у галузі фізичного виховання видатного польського вченого А. Снядецького й впливу його поглядів на подальший розвиток теорії та практики фізичного виховання дітей і молоді в Польщі.

Методи дослідження - вивчення літературних джерел, документальних й історичних матеріалів, теоретичний аналіз і синтез отриманих даних.

Результати дослідження. Анджей Снядецький (1768-1838) - видатний польський хімік, біолог, лікар, але також філософ та педагог, яскравий приклад представника епохи Просвітництва. Його 
вважають батьком хімічних наук, гігієни, дієтології й фізичного виховання в Польщі. Анджей Снядецький народився в містечку Жнін неподалік від м. Бидгощі у дворянсько-міщанський сім’і (його батьки були володарями фільварку та кількох домів у самому Жниві). Його старший брат у майбутньому також зробив вражаючу наукову кар'єру - був відомим астрономом, фізиком і математиком. Він був для молодшого Анджея авторитетом та прикладом для наслідування.

У 1771 р. А. Снядецький закінчив медичний факультет Головної коронної школи в Кракові (сучасний Ягелонський університет), пізніше продовжував навчання в Павійському університет (Італія). У 25-річному віці отримав ступінь доктора філософії та медицини. У 1793-1797 рр. проходив наукове стажування в Единбурзі, Лондоні й Відні. У 1797 р. обійняв посаду професора кафедри хімії і медицини Головної Віленської школи великого князя Литовського, попередниці Віленського університету (1803р.). У період розквіту своєї наукової кар'єри А. Снядецький активно займався популяризацією нових наукових теорій, насамперед боровся з відсталістю та необізнаністю в суспільстві, часто публікуючи у «Віленському Щоденнику» (видався від 1805 р.) проникнуті їдкою сатирою та іронією статті. А. Снядецький був палким патріотом свого народу, на очах якого Польща фактично припинила існування як незалежна держава, що, безсумнівно, вплинуло на його творчу й наукову діяльність. Одним із найважливіших творів А. Снядецького, у якому він висловив свою громадянську позицію, турботу про майбутнє польського народу, про його біологічний потенціал, $є$ праця «Про фізичне виховання дітей», публікація якої розпочалась у 1805 р. у «Віленському Щоденнику» в 5-, 6- та 7-му номерах журналу. Праця складалася зі вступу та трьох розділів. У 1822 р. автор підготував нову й більш об'ємну версію роботи, яку надруковано лише в 1840 р., на жаль, уже після смерті А. Снядецького.

У 1806 р. А. Снядецький разом із німецьким лікарем, професором медицини Й. Франком відкрив у Вільні Товариство лікарів і став його першим головою.

Публікація «Про фізичним виховання дітей» поруч із виданнями першого польського підручника педіатрії Я. Шимкіевича «Наука про захворювання дітей» (1808р.) та працею Г. Пірамовича «Навчальні ігри для дітей», значна частина якої стосувалася фізичного виховання, відіграла важливу роль у становленні й розбудові теорії та практики фізичного виховання в Польщі. Особливо близькі за духом із поглядами на фізичне виховання А. Снядецького були погляди Г. Пірамовича (1735-1801), польського педагога, письменника, прихильника розвитку та розбудови системи шкільного фізичного виховання, покращення фізичного розвитку дітей у сільських умовах, їх гартування, діяльності вчителів у галузі шкільної гігієни та опіки над хворими учнями, активного діяча Комісії народної освіти.

У часи своєї молодості А. Снядецький часто подорожував країнами Європи i, як лікар, звертав особливу увагу на те, як функціонують лікарні, будинки опіки, сиротинці для дітей, що сприяло усвідомленню того, яку важливу роль відіграють медицина й система опіки для повноцінного розвитку дітей та молоді. Його позиція в цьому питанні чітко визначена в праці «Про фізичне виховання дітей».

У тому історичному періоді (друга половина XVIII ст. - початок XIX ст.) на польських землях фактично не проводилося профілактичної діяльності в галузі охорони здоров'я дітей, молоді та дорослих, що негативно впливало на рівень культури гігієни більшості населення, а особливо селян. У селах $\mathrm{i}$ провінції поширено народну медицину, яка в багатьох елементах спиралася на забобони й знахарство. Рівень смертності серед населення був високим, особливо серед дітей. Важкі побутові умови життя часто приводили до значних утрат у мирний період часу, навіть вищих, ніж під час військових дій. Не випадково А. Снядецький усвідомлював, яку важливу роль у піднесенні здоров'я польського народу може відіграти популяризація фізичного виховання й гігієнічної культури серед жителів міст і сіл.

Праця А. Снядецького «Про фізичне виховання дітей» $\epsilon$ натхненням для багатьох поколінь польських педагогів, учителів до творчої праці в цій галузі. Без сумніву, ця книга стала причиною становлення й розвитку фізичного виховання в системі освіти дітей та молоді в Польщі, у тому числі й неповносправних учнів. Погляди А. Снядецького щодо залучення неповносправних школярів до участі в заняттях із фізичного виховання відіграли значну роль у розвитку польської теорії та практики спеціальної педагогіки. Вони розвинуті в наступних десятиліттях видатним педагогом М. Гжегожевською, філософсько-педагогічна концепція якої становила широке підгрунтя щодо залучення неповносправних людей до активної участі в суспільному житті, а в ситуаціях важкого стану здоров'я - охоплення їх повноцінною державною опікою. Методи, які впроваджувала в педагогічну практику праці з неповносправними дітьми М. Гжегожевська, поєднували розумову діяльність із фізичною активністю, ураховуючи індивідуальні потреби та їхній психофізичний потенціал [1].

Одним із важливих імпульсів для написання своєї праці для А. Снядецького була значна розбіжність між тогочасними суспільним нормами та нормами сімейного вихованням дітей. А. Снядецький був кри- 
тично налаштований до домашньої системи освіти й виховання як серед шляхти, так і стосовно міщанських сімей. У своїй критиці він особливу увагу звертав на відсутність у домашній освіті та вихованні чітких засад і правних норм, однобокість процесу виховання, спрямованого переважно на розвиток духовної сфери 3 нехтуванням фізичного розвитку дітей і молоді. У своїй праці Снядецький представив власну концепцію та програму виховання дітей у сім'ї [6].

Фізичне виховання, на думку вченого, повинно охоплювати етапи розвитку людини від народження й до 25 року життя. Особливу увагу звертали на немовлячий період і до 7-го року життя дитини. Систематичні гімнастичні вправи $€$ підставою фізичного виховання в періоди від 12 до 15 року життя. До цього часу діти займаються руховою діяльністю здебільшого самостійно згідно з власним бажанням. Одночасно рухова активність у значної кількості дітей робітників та селян поєднується з не перевантаженою надмірною фізичною працею (навчання певного ремесла). Отже, діти вчаться необхідних у майбутньому умінь i навичок, потрібних дорослій людині в повсякденному житті й праці [3].

А. Снядецький був переконаний, що в процесі виховання дітей та молоді повинен бути взаємозв'язок розумової, моральної, естетичної та фізичних сфер в особовості. У своій концепції виховання він узірцем вважав поняття давньогрецької естетики, калогокогатії, що виражалася в ідеальному єднанні фізичної краси та духовної досконалості. Фізичне виховання він називав основою процесу виховання, тому що воно зумовлює реалізацію всіх життєвих цінностей. Серед практичних засобів виділено роль і значення для повноцінного розвитку дітей та молоді народних рухливих ігор. Також усвідомлено вагу індивідуального підходу до кожного учня в навчальному процесі.

Те, що А. Снядецький отримав медичну освіту, суттєво визначило його погляди на цілі й завдання фізичного виховання. Найважливішою метою у своій концепції він вважав створення відповідних умов для збереження та зміцнення здоров'я дітей і молоді, а сам процес реалізації цієї мети називав лікарським вихованням, яке зумовлює умови для суспільного добробуту й щастя людини [3].

У концепції А. Снядецького найважливішим засобом виховного впливу вчителя на учня $\epsilon$ фізична активність, яка стимулює фізичний розвиток організму дитини й сприяє збереженню та зміцненню його здоров'я. Вартість здоров'я також залежить від стилю життя батьків перед народженням дитини, а також процесу опіки над дитиною після іiї народження, що в наступних роках іiі життя зумовлює моральний та інтелектуальний розвиток [5].

Погляди на виховання А. Снядецького можна сприймати також, як певний декалог, спадщину для наступних поколінь, яка втілювалась у таких тезах: кожний етап виховного процесу повинен мати творчий характер; виховання завжди належить до чітко визначеного етапу онтогенезу людини; процес виховання охоплює всі аспекти іiі життя; виховання проходить у тісному зв'язку з навколишнім середовищем; метою виховання $\epsilon$ формування всебічно розвинутої людини; фізичне виховання розпочинається від моменту народження людини; фізичне виховання $є$ біологічною потребою людини та ії суспільним обов'язком; виховання $є$ процесом індивідуальним, але його результати суттєво впливають на функціонування всього суспільства; одним із найважливіших елементів виховання є гра [4].

Шануючи індивідуальність дитини, А. Снядецький пропонував залишати ій якомога більше свободи, учити почуття честі, не застосовувати тілесних покарань. Із фізичних вправ, на думку А. Снядецького, найкращі для розвитку учнів $\epsilon$ танець, фехтування, кінний спорт, боротьба, рухливі ігри на свіжому повітрі, набування практичних умінь, які потрібні в наступному дорослому житті. Значну увагу приділено гартуванню організму дітей. А. Снядецький запропонував, щоб діти якнайбільше часу перебували на свіжому повітрі, часто влітку ходили босоніж, а водні процедури мають бути щоденними, дітей треба навчити плавати й вони повинні якомога частіше приймати різноманітні водні процедури. Харчування мусить бути здоровим, збалансованим, у ранньому дитинстві потрібно обмежувати дітям споживання м'ясних страв.

Етап виховання малої дитини повинен бути періодом фізичного виховання, процес навчання має розпочинатися дещо пізніше. Фактично спостереження природи стає головним виховним методом. Вільний час дитини бажано витрачати на рухливі ігри та фізичні вправи, такі як біг, стрибки, вправи 3 рівноваги, подолання теренових перешкод і працю в огороді. Діти в старшому віці повинні збагачувати свій досвід, учитися підстав полювання, виконувати вправи з вільної боротьби. Фізичні вправи повинні підготувати дітей до інтелектуального й морального розвитку. Виховання має проходити в природних умовах, таким чином готувати дітей до дорослого життя [5].

Загалом А. Снядецький, як і Г. Пірамович, був прихильником виховання дітей у сільських умовах, а не в місті, де, на його думку, дитина не може отримати кращі умови до фізичного розвитку.

Снядецький, пропагуючи фізичне виховання, часто порівнює його з моральним вихованням дітей, натомість інтелектуальне виховання, на думку вченого, підпорядковане моральному вихованню. Одно- 
часно А. Снядецький чудово розумів єдність цих трьох складових частин процесу виховання, головною метою якого є всебічний розвиток молодої людини.

Погляди А. Снядецького на роль і місце фізичного виховання дітей та молоді мали також низку дискусійних аспектів. На нашу думку, це, передусім, стосується не повного врахування значення навчального процесу із загальноосвітніх предметів у молодшому шкільному віці, у якому, на думку вченого, повинно, як уже зазначено вище, повністю домінувати фізичне виховання та навчання основ певного ремесла.

Суттєвим аспектом програми виховання дітей і молоді А. Снядецького є його демократичний характер стосовно всього суспільства без поділу на класи.

Висновки. Просвітницька, наукова та педагогічна діяльність А. Снядецького проходила в складних політично-суспільних умовах занепаду польської державності та поділу польських земель між Росією, Пруссією й Австро-Угорщиною, що значно впливало на формування в нього концепції фізичного виховання дітей і молоді в польському суспільстві.

Ключову роль, на думку вченого, у всебічному вихованні дітей і молоді повинно відігрівати фізичне виховання, суттєвим елементом якого є рухова активність на свіжому повітрі та гартування й гігієна тіла.

\section{Джерела та література}

1. Maszczak T. Jędrzej Śniadecki jako prekursor wychowania fizycznego specjalnego, [w:] Frołowicz T. (pod red.), Jędrzej Śniadecki o fizycznym wychowaniu dzieci - 200 lat później. Gdańsk, 2005.

2. Ośiński W. Problemy auksologiczne w rozprawie Jędrzeja Śniadeckiego «O fizycznym wychowaniu». Wychowanie Fizyczne i Zdrowotne. Nr 5. 2006. S. 5-11.

3. Śniadecki J. O fizycznym wychowaniu dzieci. Warszawa: Wydawnictwo Akademickie «Żak», 2010.147 s.

4. Zuchora K. Co nam dał Jędrzej Śniadecki? Wychowanie Fizyczne i Zdrowotne. Nr 10. 2005. S. 9-11.

5. Żiółkowski A., Frołowicz T. Polska koncepcja wychowania fizycznego wg Jędrzeja Śniadeckiego. Lider. Nr 10. 2011. S. 14-17.

6. Fryckowski E. Jędrzej Śniadecki - wybitny myśliciel polskiego Oświecenia, Zeszyty Naukowe Wyższej Szkoły Pedagogicznej w Bydgoszczy. Studia z Nauk Społecznych. Z. 10. 1993. S. 17-31.

7. Вільчковський Е. С., Пасічник В. Р. Фізичне виховання учнів загальноосвітніх шкіл Польщі XVI - початок XXI ст. (історичний аспект)/ Кельцінський гуманітарно-природничий університет ім. Я. Кохановського, Луцький інститут розвитку людини Університету «Україна». Київ, 2011. С. 161.

\section{References}

1. Maszczak, T. (2005). Jędrzej Śniadecki jako prekursor wychowania fizycznego specjalnego, [w:] Frołowicz T. (Red.), Jędrzej Śniadecki o fizycznym wychowaniu dzieci - 200 lat później, Gdańsk.

2. Ośiński, W. (2006). Problemy auksologiczne w rozprawie Jędrzeja Śniadeckiego «O fizycznym wychowaniu». Wychowanie Fizyczne i Zdrowotne, 5, 5-11.

3. Śniadecki, J. (2010). O fizycznym wychowaniu dzieci. Warszawa: Wydawnictwo Akademickie «Żak», 147.

4. Zuchora, K. (2005). Co nam dał Jędrzej Śniadecki? Wychowanie Fizyczne i Zdrowotne, 10, 9-11.

5. Żiółkowski, A., Frołowicz, T. (2011). Polska koncepcja wychowania fizycznego wg Jędrzeja Śniadeckiego. Lider, 10, 14-17.

6. Fryckowski, E. (1993). Jędrzej Śniadecki - wybitny myśliciel polskiego Oświecenia, Zeszyty Naukowe Wyższej Szkoły Pedagogicznej w Bydgoszczy. Studia z Nauk Spotecznych, 10, 17-31.

7. Viljchkovsjkyj, E. S., Pasichnyk, V. R. (2011). Fizychne vykhovannja uchniv zaghaljnoosvitnikh shkil Poljshhi XVI - pochatok XXI ct. (istorychnyj aspekt). Keljcinsjkyj ghumanitarno-pryrodnychyj universytet im. Ja. Kokhanovsjkogho, Lucjkyj instytut rozvytku ljudyny Universytetu «Ukrajina», Kyjiv, 161.

Стаття надійшла до редакції 17.05.2019 p. 